\title{
Responsibility to Protect sebagai Bentuk Perlindungan Hak Asasi Manusia di ASEAN
}

\author{
Norilla \\ University of Jember, Indonesia \\ nurillah02@gmail.com \\ Eddy Mulyono \\ University of Jember, Indonesia \\ eddy_mulyono.fh@unej.ac.id
}

\begin{abstract}
Association of Southeast Asian Nations (ASEAN) established on August 8, 1967 still accords to the principle of non-intervention which has been arranged in the ASEAN Charter. This principle, however, has been debated among ASEAN members, specifically when it is dealt with human rights. While the instutionalization is one of ASEAN's achievements, human rights become one of pivotal issues in Southeast Asia which subsequently raises questions on the commitment of ASEAN to support the Responsibility to protect at the Summit on 2005. This article revisits the responsibility to protect in international law which is accorded to international customary law of Article 38 paragraph (1) of the Statute of International Court of Justice (ICJ). By legal research, this article asserts that the responsibility to protect is essentially applicable to be adopted by regional intergovernmental organization like ASEAN, though it was initially only adopted by the Security Council of the United Nations. But, the principle of non-intervention would be the primary barrier to applying it. Therefore, this article recommends to wielding power to the Security Council of the United Nations with respect to solving such problem at the ASEAN level with the following idea to include ASEAN as the UN member.
\end{abstract}

KEYWORDS: Responsibility to protect, Human Rights, ASEAN.

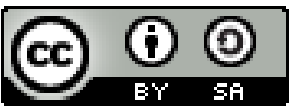

Copyright $\odot 2018$ by Author(s)

This work is licensed under a Creative Commons Attribution-ShareAlike 4.0 International License. All writings published in this journal are personal views of the authors and do not represent the views of this journal and the author's affiliated institutions.

\section{HOW TO CITE:}

Norilla \& Eddy Mulyono. "Responsibility to Protect sebagai Bentuk Perlindungan Hak Asasi Manusia di ASEAN” (2018) 5:1 Lentera Hukum 17-30.

Submitted: December 18, 2017 Revised: February 02, 2018 Accepted: April 23, 2018 


\section{PENDAHULUAN}

Responsibility to protect adalah sebuah norma yang disepakati secara internasional guna melindungi warga negara dari suatu kejahatan. ${ }^{1}$ Norma ini tidak serta merta lahir dari rahim perjanjian internasional ataupun kebiasaan internasional, tetapi konsep ini lahir dari sejarah yang bermula pada tahun 1990-an. Pada saat itu, dunia dihebohkan dengan pembunuhan massal yang terjadi di Bosnia, Rwanda dan Kosovo.

Salah satunya, pembunuhan terhadap suku Tutsi yang dipimpin oleh Akazu yang merupakan kelompok mayoritas dari suku Hutu di Rwanda. Tercatat peristiwa ini menelan korban sebanyak 850.000 orang. ${ }^{2}$ Sayangnya, Perserikatan Bangsa-Bangsa (PBB) dinilai gagal dalam menindak kejahatan ini. Salah satu alasannya adalah perbedaan persepsi antar negara-negara anggota yang terbagi ke dalam dua kelompok. Salah satu kelompok berpendapat bahwa perlunya sikap intervensi kemanusiaan apabila terjadi pembunuhan massal, sedangkan kelompok lain tetap berpegang teguh terhadap konsep kedaulatan negara. ${ }^{3}$

Dalam tataran hukum internasional, kedaulatan menjadi landasan dari tatanan dunia di mana suatu wilayah akan selalu membentuk persepsi terkait batasan yang ditentukan oleh garis geografis. Atas dasar ini, kedaulatan negara menunjukkan diri sebagai kesetaraan hukum antar negara dengan sebuah kebebasan bertindak tanpa campur tangan dari negara lain, baik tindakan politik, ekonomi ataupun kebijakan lain dalam negara tersebut. ${ }^{4}$

Sehubungan dengan Pasal 2 Piagam PBB yang menyatakan bahwa tidak ada satupun ketentuan di dalam Piagam PBB yang memberikan kuasa kepada PBB untuk melakukan intervensi mengenai masalah yang berkaitan dengan yurisdiksi nasional suatu negara. ${ }^{5}$ Sebagaimana disebutkan di atas kedaulatan antar negara memberi persetujuan bahwa mewujudkan keamanan dan perdamaian internasional harus senantiasa dilandaskan atas persamaan kedaulatan negara.

Hal inilah yang mendorong lahirnya prinsip nonintervensi. Nonintervensi selalu dikaitkan dengan sikap suatu negara yang tidak mencampuri urusan dalam negeri dari negara lain sehingga menolak doktrin intervensi kemanusiaan (humanitarian intervention). Sebagaimana pernyataan dari John Mark Lyi, bahwa intervensi yang dilakukan oleh negara, negara bagian domestik ataupun organisasi internasional, terkadang tidak memerlukan keabsahan hukum karena telah menjadi pola dari suatu hubungan internasional. ${ }^{6}$

International Coalition for The Responsibility to protect, 'Sebuah Toolkit tentang Tanggung Jawab Melindungi', hlm. 15.

2 Santa Marelda Saragih, 'Responsibility to protect: Suatu Tanggung Jawab dalam Kedaulatan Negara' 2, MeiAgustus 20ll, hlm. 2.

3 International Coalition, supra note 1, hlm. 6.

4 John Mark Lyi, Humanitarian Intervention and the AU-ECOWAS Intervention Treaties under International Law: Towards a Theory of Regional Responsibility to protect (Springer International Publishing AG Switzerland 2016), hlm. 65.

5 Lihat Pasal 2 ayat 7 UN Charter.

6 John Mark Lyi, supra note 4, hlm. 42. 
Akibatnya, terjadi perdebatan karena pengaturan intervensi kemanusiaan tidak diatur secara eksplisit di dalam Piagam PBB. Apalagi, humanitarian intervention berpotensi menimbulkan kekacauan ${ }^{7}$ dengan mengartikan bahwa negara adidaya dapat melakukan intervensi kepada negara lain sebagaimana invansi yang dilakukan Amerika kepada Irak pada tahun $2003 .^{8}$

Situasi ini memicu reaksi dari Kofi Annan, ${ }^{9}$ dengan menantang anggota PBB untuk menemukan suatu formula yang mampu menjadi legitimasi untuk melakukan suatu intervensi dalam melindungi Hak Asasi Manusia (HAM). ${ }^{10}$ Menjawab tantangan tersebut, Francis Deng ${ }^{11}$ menyatakan bahwa kedaulatan negara harus didasarkan pada perlindungan terhadap rakyat yang tinggal di dalam wilayah tersebut, bukan atas dasar kehendak negara itu sendiri tanpa ada campur tangan internasional. Ide ini kemudian dikembangkan oleh ICISS (International Commission on Intervention and State Sovereignty), ${ }^{12}$ yang melahirkan sebuah prinsip dengan nama responsibility to protect.

Prinsip ini akhirnya menjawab kegagalan komunitas internasional dalam menghentikan pembunuhan massal di Bosnia, Rwanda dan Kosovo. Lebih lanjut, prinsip ini dibawa ke dalam Konferensi Tingkat Tinggi (KTT) pada tahun 2005 yang melahirkan "The World Summit Outcome Document. Salah satu capaian terpenting di dalam konferensi ini adalah adanya kesepakatan antar negara anggota PBB bahwa semua negara anggota siap mengambil tindakan kolektif apabila suatu negara gagal melindungi rakyatnya dari kejahatan genosida. Komitmen ini kemudian dikukuhkan dalam Resolusi Majelis Umum PBB Nomor A/60/I tanggal 24 Oktober 2005. ${ }^{13}$

Berdasarkan laporan ICISS, responsibility to protect memiliki tiga tanggung jawab yang harus diterapkan, diantaranya untuk mencegah pemusnahan massal dan kejahatan kemanusiaan lainnya. Ini menjadi tanggung jawab setiap negara sekaligus komunitas internasional untuk menangani penyebab konflik, seperti kemiskinan, penyebaran sumber daya, serta tekanan ekonomi. Tanggung jawab untuk merespon suatu situasi ketika pembunuhan massal, pembersihan etnis atau kejahatan kemanusiaan yang telah berlangsung atau akan segera terjadi. Tanggung jawab untuk

7 Eric A Heinze, Waging Humanitarian War: The Ethics, Law and Politics of Humanitarian Intervention (State University of New York Press, Albany 2009), hlm. 8.

8 Ion Panait, 'From Human Security to responsibility to protect' (2014) Lucian Blaga University, hlm. 2.

9 Sekretaris PBB Periode 1997-2006.

10 Pernyataan asli Kofi Annan: ...cast in stark relief the dilemma of so-called "humanitarian intervention". On the one hand, is it legitimate for a regional organisation to use force without a UN mandate? On the other, is it permissible to let gross and systematic violations of human rights, with grave humanitarian consequences, continue unchecked? The inability of the international community to reconcile these two compelling interests in the case of Kosovo can be viewed only as a tragedy. Dikutip di Stephen P Marks and Nicolas Cooper, 'The responsibility to protect: Watershed or Old Wine in a New Bottle' 2, Issue 1, September 2010 O. P. Jindal Global University, hlm. 5 .

Il Seorang mantan diplomat asal Sudan yang menjadi Perwakilan Khusus PBB untuk Masalah Pengungsi Internal.

12 Suatu lembaga yang dibentuk oleh Pemerintah Kanada pada bulan September 2000 yang dipimpin oleh sejumlah ahli internasional seperti Gareth Evans dan Mohammed Sahnoun guna mengembangkan prinsip R2P atas dasar hasil pemikiran Dr. Francis Deng.

13 Rahayu, 'Eksistensi Prinsip Responsibilty to Protect Dalam Hukum Internasional' Jilid 41 No. 1 Januari 2012 Jurnal MMH 3. 
membangun setelah terjadinya pembunuhan massal dan kejahatan kemanusiaan. Negara secara individual dan komunitas internasional bertanggung jawab untuk memberikan bantuan kepada masyarakat yang telah mengalami kejahatan genosida untuk dapat pulih, membangun dan berdamai setelah konflik terjadi.

Sebagaimana Ban Ki Moon ${ }^{14}$ telah menyiapkan rencana pelaksanaan responsibility to protect ke dalam tiga pilar, ${ }^{15}$ pilar pertama yaitu tanggung jawab untuk melindungi sesuatu yang dimiliki oleh negara-negara. Pilar ini menekankan bahwa setiap negara memiliki kewajiban untuk melindungi rakyatnya dari kejahatan HAM. Bahkan, Sekjen PBB ini memberikan beberapa rekomendasi mengenai bentuk tanggung jawab ini, seperti menjamin adanya mekanisme yang efektif apabila terjadi suatu konflik, atau melindungi kelompok minoritas di dalam suatu negara dengan merefleksikan diri guna memahami responsibility to protect.

Pilar kedua yaitu bantuan internasional dan pembangunan kapasitas (capacity building). Pilar ini mencantumkan kewajiban komunitas internasional untuk menyediakan bantuan bagi setiap negara yang sedang mengalami krisis kemanusiaan semisal dengan membentuk tim 'reaksi cepat' sipil dan militer pada tingkat regional untuk membantu negara yang sedang konflik. Namun, menurut Ban Ki Moon, ada kalanya pilar kedua ini harus diterapkan sebelum pecahnya konflik dan pencegahan adalah alternatif yang terbaik guna menghentikan krisis yang terjadi.

Pilar ketiga adalah respon tepat waktu dan tegas terhadap krisis kemanusiaan. Pilar ini menegaskan agar komunitas internasional wajib mengambil langkah tepat waktu dan tegas guna menghentikan krisis dan konflik. Langkah ini dapat dilakukan oleh PBB dan/atau setiap organisasi regional dan subregional. Misalnya, Dewan Keamanan PBB dan Majelis Umum PBB membentuk misi pencari fakta guna menyelediki pelanggaran yang terjadi. Langkah ini dapat menjadi peringatan dini bagi pemerintah setempat sehingga PBB dapat memutuskan langkah berikutnya semisal dengan bekerja sama dengan organisasi regional atau subregional dalam menyelesaikan konflik kemanusiaan tersebut.

Dari penjelasan tersebut, R2P memang baru secara resmi dikukuhkan dalam Resolusi Majelis Umum PBB pada tahun 2005. Namun sebenarnya, responsibility to protect telah memiliki dasar hukum yang tercantum di Deklarasi Universal Hak Asasi Manusia (DUHAM) 1948. Meskipun sebatas deklarasi, DUHAM dapat diterima oleh semua negara karena pernyataan di dalamnya berangkat dari kebiasaan internasional. Sedangkan, menurut pasal 38 ayat (1) Mahkamah Internasional (ICJ) sebagai salah satu sumber hukum internasional adalah kebiasaan internasional. Artinya, kebiasaan internasional yang terdapat di dalam DUHAM inilah yang menjadi dasar pijakan, bahwa responsibility to protect dapat diterima oleh semua negara karena menyangkut hak

14 Sekjen PBB yang menjabat dua periode berturut-turut dimulai dari tanggal l Januari 2007 sampai 31 Desember 2016.

15 Tiga pilar ini disampaikan dalam laporan Ban Ki Moon pada tahun Januari 2009 yang berjudul "Implementing responsibility to protect". Laporan ini merupakan dokumen pertama PBB yang paling lengkap mengenai prinsip R2P dimana, Sekjen PBB ini mengungkapkan rencana-rencananya untuk menerapkan "Responsibility to protect" dalam bentuk tindakan nyata. 
asasi. Perlindungan terhadap hak asasi, sudah dilakukan sejak zaman dulu seperti latar belakang terjadinya Magna Charta atau Revolusi Perancis. Oleh karena itu, responsibility to protect lahir karena kebiasaan internasional terutama dalam perlindungan HAM.

Jika dicermati lebih lanjut, responsibility to protect juga tidak bertentangan dengan Piagam PBB karena di akhir Pasal 2 ayat (7) memberikan pengecualianbahwa suatu intervensi bisa saja disimpangi berdasarkan ketentuan Bab VII. ${ }^{16}$ Sebagaimana Bab VII mengatur bahwa satu-satunya badan yang berhak melakukan intervensi demi keamanan internasional adalah Dewan Keamanan PBB. Dengan demikian, responsibility to protect adalah prinsip yang lahir dari tubuh PBB dan hanya PBB yang bisa melakukan intervensi kemanusiaan di bawah kendali Dewan Keamanan PBB. Artinya, PBB memberikan ruang untuk melakukan intervensi kemanusiaan demi melindungi HAM.

Fakta ini berbanding terbalik dengan yang terjadi di ASEAN. Prinsip nonintervensi yang telah dilegalisasi dalam Piagam ASEAN, tidak memberikan ruang untuk melakukan intervensi sehingga bersifat absolut dan kaku. Akibatnya, ASEAN menjadikan prinsip persamaan kedaulatan sebagai prinsip utama dengan ciri khas saling melakukan musyawarah yang disahkan di dalam Piagam ASEAN ${ }^{17}$ dengan menghindari penyelesaian masalah melalui cara kekerasan apalagi ikut campur ke dalam urusan pemerintahan suatu negara. Dengan demikian, ASEAN tidak mengenal kata intervensi dalam penyelesaian sengketa kawasan. Sehingga, secara tersirat, negaranegara anggota menganggap bahwa cara penyelesaian terbaik adalah secara internal atau nasional. ${ }^{18}$

Salah satunya, kasus pelanggaran kemanusiaan terhadap etnis Rohingya yang terjadi sejak rezim junta militer berkuasa di Myanmar. Peristiwa ini terjadi karena pemerintah Myanmar menganggap Rohingya bukanlah masyarakat pribuminya, melainkan warga pendatang yang ditempatkan oleh penjajah Inggris dari Bangladesh. Selain itu, dengan dibuatnya UU Kewarganegaraan Myanmar 1982, etnis Rohingya resmi dideklarasikan sebagai warga asing di Myanmar. Hal ini sering memunculkan pelanggaran HAM yang terjadi terhadap etnis Rohingya dengan tujuan untuk mengusir keberadaan mereka dari wilayah Myanmar. ${ }^{19}$

Tindakan yang dilakukan Myanmar terhadap etnis Rohingya tersebut, adalah bukti bahwa ASEAN seharusnya melakukan tindakan sebagai upaya tanggung jawab bersama dalam melindungi penduduk di dalam suatu negara. Karena pada hakekatnya, terbentuknya suatu organisasi internasional adalah sebagai wujud untuk mencapai kedamaian dunia. Apalagi, negara anggota ASEAN menyetujui responsibility to protect pada World Summit tahun 2005 lalu. Artinya, negara anggota ASEAN sepakat untuk

16 Pasal 2 ayat (7) UN Charter “...........but this principle shall not prejudice the application of enforcement measures under Chapter VII".

17 Setelah diratifikasi 10 negara, ASEAN charter mulai berlaku pada tanggal 15 Desember 2008. Setelah Piagam ini berlaku, maka kesepuluh negara terikat dengan apa yang diatur oleh Piagam ASEAN.

18 Christine Susanna Tjhin, 'Menjalin Demokrasi Lokal dengan Regional: Membangun Indonesia, Membangun Asean' (Centre for Strategic and International Studies 2005), hlm. 6.

19 Irma D Rismayati, 'Manusia Perahu Rohingya: Tantangan Penegakan HAM di ASEAN' l Oktober 2009, hlm. 17. 
melakukan intervensi kemanusiaan demi hak asasi dan wajib menerapkan responsibility to protect di kawasan ASEAN. Namun, satu-satunya badan yang bisa menerapkan responsibility to protect hanya Dewan Keamanan PBB. Hal ini yang menjadi pertanyaan, apakah responsibility to protect bisa diterapkan di ASEAN yang sebatas merupakan organisasi regional.

\section{PEMBAHASAN}

Sekilas, sebenarnya ASEAN memiliki ASEAN Intergovermental Commision of Human Rights (AICHR). Di dalam Term of References dijelaskan bahwa dalam rangka menjalankan tugas, Badan HAM ini harus menghormati prinsip yang tercantum di dalam Pasal 2 Piagam ASEAN. Jika dicermati, terdapat kontra argumen dalam penerapannya. Di satu sisi, AICHR bertindak sebagai Badan HAM yang memiliki tugas promosi dan perlindungan hak asasi, di sisi yang lain harus menghormati prinsip yang dianut ASEAN yaitu, prinsip nonintervensi. Maka, sangat wajar apabila sampai saat ini, AICHR seolah-olah sebagai macan tanpa taring karena kedudukannya sangat pasif dan statis.

Apabila hal ini terus dibiarkan, tidak menutup kemungkinan pelanggaran hak asasi seperti kasus Rohingya akan terulang kembali. Padahal, salah satu bentuk pencegahan adalah dengan menerapkan responsibility to protect. Sebagaimana responsibility to protect adalah prinsip yang lahir di badan PBB dan dieksekusi oleh Dewan Keamanan PBB karena hanya organ inilah yang memiliki fungsi spesifik dalam upaya menjaga stabilitas keamanan internasional. Kendati lahir dan dieksekusi oleh PBB, responsibility to protect dapat diterapkan di wilayah ASEAN dengan cara melakukan KTT ASEAN.

Konferensi ini dilakukan dalam rangka mewujudkan pasukan penjaga perdamaian (peackeeping force) dalam tingkat ASEAN dan melakukan amandemen Piagam ASEAN. Dua hal ini sangat diperlukan untuk menerapkan responsibility to protect di ASEAN. Sebagaimana organisasi lainnya, puncak suatu organisasi terjadi pada saat pertemuan semua kepala negara yang disebut KTT. KTT ASEAN merupakan forum pertemuan kawasan yang bersifat terbuka guna membahas isu ekonomi dan politik yang menjadi perhatian bersama dalam rangka mewujudkan perdamaian dan stabilitas kawasan. ${ }^{20}$

Oleh karena itu, KTT adalah kesempatan untuk mewujudkan responsibility to protect dengan dua langkah di atas. Pertama, mewujudkan pasukan penjaga perdamaian dalam tingkat ASEAN. Sejatinya, pasukan penjaga perdamaian memang tidak diatur secara khusus di dalam Piagam PBB, namun dapat ditemukan di dalam Pasal 29 yang menyatakan:

20 Direktorat Jenderal Kerja Sama ASEAN Kementerian Luar Negeri RI, Ayo Kita Kenali Asean (2011), hlm. 44. 
"...Peacekeeping as such, is not specially provided for in the Chapter, except for the provision that 'The Security Council may establish such subsidiary organs as it deems necessary for the performance of its functions."

Pasukan Penjaga Perdamaian PBB ini, baik militer, polisi atau sipil dalam menjalankan mandatnya, diwajibkan untuk menghormati hak asasi sekaligus memajukan HAM. Dengan demikian, pasukan penjaga perdamaian ini dapat merespon secara tepat sesuai mandat yang diterima. ${ }^{21}$

Langkah kedua yaitu melakukan amandemen Piagam ASEAN khususnya mengenai prinsip nonintervensi. Sebagaimana perjanjian internasional pada umumnya, Piagam ASEAN telah menjadi perjanjian yang bersifat iktikad baik (good faith) antar para pihak, sehingga berimplikasi terhadap semua negara anggota ASEAN yang telah meratifikasi. ${ }^{22}$ Akibatnya, perjanjian yang tercantum di dalam Piagam ASEAN ini mengikat seluruh negara dan mewajibkan para pihak untuk melaksanakannya dengan iktikad baik. ${ }^{23}$ Dengan demikian, tidak menutup kemungkinan untuk diadakan amandemen dalam perjalanannya.

Sebagaimana yang dijelaskan oleh Kholis Roisah bahwa dalam konteks hukum perjanjian internasional, amandemen harus dilakukan secara formal dengan tujuan mengubah ketentuan-ketentuan yang berhubungan dengan semua pihak, ${ }^{24}$ Di dalam Pasal 49 mengatur mengenai tata cara amandemen, di mana setiap negara dapat mengusulkan amandemen yang diajukan kepada Dewan Koordinasi ASEAN secara konsensus agar diputuskan pada saat Konferensi Tingkat Tinggi. ${ }^{25}$ Supaya amandemen ini dapat terlaksana, harus ada suatu negara yang memulai mengusulkan amandemen.

Terlepas dari negara yang memiliki inisiatif untuk mengusulkan amandemen, perubahan perjanjian internasional ini harus mencakup hal yang mendasar yaitu amandemen terhadap prinsip nonintervensi. Dengan demikian, sudah seharusnya prinsip nonintervensi diberi ruang pengecualian layaknya prinsip nonintervensi yang diatur di dalam piagam PBB, sehingga prinsip ini tidak lagi bersifat absolut dan kaku.

Pengecualian di sini adalah sebuah keadaan yang memungkinkannya dilakukan sebuah intervensi kemanusiaan. Dengan mengamandemen prinsip nonintervensi yang diatur di dalam Piagam ASEAN, maka intervensi kemanusiaan yang akan dieksekusi oleh pasukan penjaga perdamaian ASEAN memiliki payung hukum dan tidak melanggar hak asasi.

Hasilnya, Pasal 14 Ayat 1 yang berbunyi, "Selaras dengan tujuan-tujuan dan prinsipprinsip Piagam ASEAN terkait dengan pemajuan dan perlindungan hak-hak asasi dan kebebasan

21 Departement of Peacekeeping Operations United Nations Secretariat, United Nations Peackeeping Operations: Principles and Guideliness, New, York. (2010), hlm. 10.

22 Harjono, 'Perjanjian Internasional dalam Sistem UUD 1945' 04, Januari-April 2012 Jurnal Opinio Juris, hlm. 14.

23 Sefriani, 'Pengakhiran Sepihak Perjanjian Perdagangan Internasional' 2 Nomor 1 Tahun 2015 Jurnal Ilmu Hukum, hlm. 17.

24 Kholis Roisah, Hukum Perjanjian Internasional: Teori dan Praktek (Setara Press 2015), hlm. 67.

25 Bunyi asli Pasal 49 "Unless otherwise provided for in this Charter, the ASEAN Coordinating Council shall determine the terms of reference and rules of procedure and shall ensure their consistency". 
fundamental, ASEAN wajib membentuk badan hak asasi manusia ASEAN" akan bersifat dinamis. Dengan kata lain, AICHR tidak lagi menjadi badan yang bersifat pasif karena prinsip nonintervensi telah memberikan ruang kepada AICHR untuk menjadi badan yang dapat menyelesaikan suatu konflik dengan keadaan tertentu.

Sebagaimana dua tujuan tersebut, yaitu mewujudkan peackeeping forces ASEAN sebagai taring dalam menjaga stabilitas keamanan dengan payung hukum prinsip nonintervensi yang telah diamandemen, responsibility to protect dapat diterapkan di dalam tubuh ASEAN. Apabila negara-negara anggota khawatir bahwa ASEAN tidak memiliki wewenang untuk melakukan intervensi kemanusiaan, terdapat tiga alasan yang menjadi landasan dalam artikel ini.

Pertama, wewenang PBB terhadap organisasi regional yang sejatinya Pasal 53 ayat 1 Piagam PBB telah memunculkan dasar hukum yang menyatakan bahwa Dewan Keamanan PBB dapat menggunakan organisasi regional untuk melakukan tindakan pemaksaan. Jika diteliti kembali, pasal ini merupakan wujud desentralisasi antara PBB kepada organisasi regional karena memberikan wewenang kepada organisasi regional untuk melakukan suatu tindakan intervensi. Sehingga, responsibility to protect yang diterapkan di ASEAN tidaklah bertentangan secara hukum karena sudah diatur di dalam Piagam PBB itu sendiri.

Kedua, ASEAN sebagai anggota dari PBB. Salah satu tujuan didirikannya PBB adalah untuk menjaga perdamaian dan keamanan dunia internasional. Hal ini disebutkan dalam Pasal 1 Ayat (1) Piagam PBB:

"To maintain international peace and security, and to that end:to take effective collective measures for the prevention and removal of threats to the peace, and to the bring about by peaceful means, and in conformity with the principles of justice and international law, adjustment or settlement of international disputes or situations which might lead to a breach of peace"

Pasal ini menjelaskan bahwa setiap negara memiliki peranan dan fungsi untuk menjaga perdamaian dan keamanan dunia internasional. Termasuk ASEAN sebagai organisasi regional.

Sebagai organisasi regional, ASEAN terdiri dari beberapa negara anggota yang keseluruhannya tercatat sebagai anggota PBB. Maka, sudah selayaknya sebagai negara anggota PBB harus mendukung segala upaya penegakan HAM baik di dalam maupun di luar negaranya. ${ }^{26} \mathrm{Hal}$ ini termaktub di Pasal 2 Ayat (2) Piagam PBB yang berbunyi, "All Members, in order to ensure to all of them the rights and benefits resulting from membership, shall fulfil in good faith the obligations assumed by them in accordance with the present Charter."

Berdasarkan Pasal 53 ayat (1) Piagam PBB, negara anggota wajib untuk menyelesaikan sengketa di wilayahnya dengan mengedepankan penyelesaian secara damai. Namun, hal ini tidak menutup kemungkinan melakukan tindakan kekerasan dengan cara desentralisasi kewenangan terhadap organisasi regional. Desentralisasi

26 Ludiro Madu, 'Pelembagaan Regional Mengenai Hak Asasi Manusia Di ASEAN' 5 Edisi 1/April 2016 Jurnal Hubungan Internasional, hlm. 7. 
kewenangan ini selaras dengan tiga pilar ASEAN, yaitu Komunitas Keamanan ASEAN (ASEAN Security Community/ASC), Komunitas Ekonomi ASEAN (ASEAN Economic Community/AEC) dan Komunitas Sosial-Budaya ASEAN (ASEAN Socio-Cultural Communityf ASCC) ${ }^{27}$

Khusus untuk pilar Keamanan, salah satu instrumen terpenting dalam rangka mewujudkan keamanan kawasan adalah dengan mengacu terhadap Treaty of Amity and Cooperation in Southeast Asia (TAC). TAC juga mengatur prinsip yang diakui Piagam PBB di antaranya prinsip 'noninterference'. TAC terbentuk pada KTT ASEAN di Bali pada tahun 1976. Perjanjian ini lahir atas dasar perbedaan atau perselisihan kepentingan antar anggota sehingga harus diatur secara rasional, efektif, dan prosedur untuk menghindari dampak yang membahayakan kerjasama antar negara anggota. ${ }^{28}$

Ketigaadalah pemilihan KTT sebagai kesempatan untuk mewujudkan responsibility to protect di ASEAN. Dengan kata lain, KTT yang berisi pertemuan seluruh kepala negara merupakan suatu kesempatan yang memiliki power yang dalam hubungan internasional terminologi 'power' selalu dikenal sebagai 'kekuasaan politik'. ${ }^{29}$ Hal ini mengindikasikan bahwa para pemimpin negara merupakan titik pusat faktor politik yang mengandung dimensi-dimensi transnasional. ${ }^{30}$ Dengan demikian, dalam artikel ini tidak ingin mencampuradukkan antara politik dan hukum. Sebagaimana pernyataan John Austin bahwa hubungan hukum dan politik memiliki sejarah panjang. Menurut Austin, hukum adalah produk dari politik atau kekuasaan. ${ }^{31}$

Sedangkan Mahfud MD menjelaskan bahwa pernyataan 'hukum sebagai produk politik' tidak dapat disalahkan. Sebaliknya, hukum yang lebih determinan dari politik. Hal ini tergantung pada asumsi dan konsep yang dipergunakan. Artinya, hukum dapat determinan dari politik, tetapi sebaliknya, politik dapat determinan dari hukum. Secara ilmiah, semuanya benar menurut asumsi dan konsepnya masing-masing karena di dalam ilmu sosial dan humaniora, tidak ada kebenaran mutlak, yang ada hanyalah kebenaran relatif. ${ }^{32}$

Sebagaimana tiga alasan tersebut, dapat ditarik garis lurus bahwa ASEAN sedang mengalami krisis hak asasi, karena sesungguhnya berbicara terkait hak asasi, tentu berbicara tentang kemanusiaan. Adapun kemungkinan penerapan responsibility to protect di ASEAN, dapat dilihat dari perbandingan mekanisme HAM regional antara ASEAN, Eropa, Amerika dan Afrika. Eropa sendiri menganut sistem bikameral atau dua kamar

27 Elfia Farida, 'Peluang dan Tantangan ASEAN Menuju Komunitas ASEAN 2015' Jilid 41 No. 3 Juli 2012 Jurnal MMH, hlm. 2.

28 Endah Rantau Itasari, 'Memaksimalkan Peran Treaty of Amity and Cooperation in Southeast Asia 1976 (TAC) dalam Penyelesaian Sengketa di ASEAN' 1 Nomor 1 Februari 2015 Jurnal Komunikasi Hukum, hlm. 7.

29 Scott Burchill and Andew Linklater, Teori-Teori Hubungan Internasional (Nusa Media Ujung, Bandung, 2009), hlm. 242.

30 William D Coplin and Marsedes Marbun, Pengantar Politik Internasional; Suatu Telaah Teoritis (Kedua, Sinar Baru, 1992), hlm. 436.

31 Merdi Hajiji, 'Relasi Hukum dan Politik dalam Sistem Hukum Indonesia' 2 Nomor 3 Desember 2013 Jurnal Rechtsvinding, hlm. 2.

32 Mahfud MD, Politik Hukum di Indonesia (Raja Grafindo Persada, 2012), hlm. 4. 
yaitu yaitu mekanisme European Commission of Human Rights (ECHR) sedangkan tingkatan kedua adalah European Court of Human Rights (ECHR). ${ }^{33}$

Begitu juga dengan mekanisme HAM Amerika yang serupa dengan mekanisme HAM Eropa dengan memiliki dua kamar (bicameral), yaitu Inter-American Court of Human Rights (IACHR) dan Inter-American Commission on Human Rights (IACHR). Standar sistem ini mengacu pada dua instrumen utama, yaitu American Declaration of the Rights and Duties of Man/ADRDM dan American Convention on Human Rights/ACHR. Sementara itu, di Afrika, di tingkat pengawasan dan penegakan, mekanisme HAM Afrika mengandalkan dua badan yaitu Komisi HAM Afrika (ACHPR) dan Pengadilan HAM Afrika (AFCHPR).

Hal ini berbanding terbalik dengan AICHR di mana terjadi ketidakseimbangan antara pemajuan (promotion) dan perlindungan (protection). Kenyataan ini dapat dilihat di dalam Kerangka Acuan AICHR, yang sama sekali tidak menyebutkan tugas AICHR berupa on site visit. Padahal, kegiatan ini berfungsi untuk mengumpulkan informasi tentang pelanggaran HAM di suatu negara. Informasi pelanggaran ini mustahil akan tersedia dan terwujud apabila AICHR tidak memiliki mandat untuk mengunjungi dan menelusuri wilayah yang berkonflik.

Inilah yang menyebabkan AICHR bertindak pasif tanpa memiliki taring untuk mencari kebenaran yang terjadi. Karena di saat menerima suatu pengaduan dan laporan, AICHR hanya sebatas menerima tanpa penyelesaian. Pada sisi lain, kerangka acuan juga tidak mengatur mengenai mekanisme suatu negara dalam memberikan laporan implementasi instrumen hak asasi yang diratifikasi. Padahal, bagian ini merupakan komponen fundamental yang dimiliki oleh rezim hak asasi saat ini.

Kelemahan ini diperparah dengan minimnya kontribusi negara anggota ASEAN dalam meratifikasi instrumen HAM. Hal ini dapat dilihat dari tabel berikut:

Tabel 1: Daftar Negara yang Meratifikasi Instrumen HAM

\begin{tabular}{|c|c|c|c|}
\hline Instrumen & Ratifikasi & Aksesi & Tanda tangan \\
\hline ICERD & Kamboja, Filipina & $\begin{array}{l}\text { Thailand, Indonesia, } \\
\text { Laos, Vietnam }\end{array}$ & - \\
\hline ICESR & Laos, Filipina & $\begin{array}{l}\text { Kamboja, Thailand, } \\
\text { Indonesia, Vietnam }\end{array}$ & - \\
\hline ICESR Opt. & - & - & - \\
\hline ICCPR & Laos, Filipina & $\begin{array}{l}\text { Kamboja, Thailand, } \\
\text { Indonesia, Vietnam }\end{array}$ & - \\
\hline ICCPR Opt. 1 & Filipina & - & Kamboja \\
\hline ICCPR Opt. 2 & Filipina & - & - \\
\hline CEDAW & $\begin{array}{l}\text { Indonesia, Laos, Filipina, } \\
\text { Vietnam }\end{array}$ & $\begin{array}{l}\text { Brunei, } \\
\text { Malaysia, } \\
\text { Singapura, }\end{array}$ & - \\
\hline Opt. CEDAW & Thailand, Filipina & - & Kamboja, Indonesia \\
\hline CAT & Indonesia & $\begin{array}{l}\text { Kamboja, } \\
\text { Thailand }\end{array}$ & Laos \\
\hline ICRMW & Filipina & - & Kamboja, Indonesia \\
\hline
\end{tabular}

33 Wahyudi Djafar, Ardimanto Putra and Hilman Handoni, 'Laporan Memperkuat Perlindungan Hak Asasi Manusia di Asean' (International NGO Forum on Indonesian Development, 2014) Laporan Penelitian, hlm. 58. 
Berdasarkan tabel di atas, terlihat bahwa negara-negara ASEAN lebih mengutamakan penghormatan terhadap kedaulatan negara dibandingkan memberikan perlindungan terhadap hak asasi warga negaranya. Tentu hal ini membutuhkan suatu alternatif guna menjamin hak asasi masyarakat ASEAN. Salah satunya, dengan menerapkan responsibility to protect yang dapat diimplementasikan dalam kasus Rohingya. Kelemahan dan kekurangan AICHR, serta minimnya partisipasi negara dalam meratifikasi instrumen HAM sudah seharusnya menjadi alasan perubahan di tubuh ASEAN. Bukan membiarkan pelanggaran tanpa perubahan.

\section{PENUTUP}

Meskipun lahir dari tubuh PBB, responsibility to protect bisa diterapkan di dalam wilayah regional khususnya ASEAN. Terdapat dua cara untuk menerapkannya yaitu lewat KTT ASEAN dengan tujuan membentuk pasukan penjaga perdamaian dan mengamandemen prinsip nonintervensi yang tercantum di dalam Piagam ASEAN. Pasukan penjaga perdamaian diperlukan sebagai badan pelaksana responsibility to protect, sedangkan amandemen terhadap prinsip nonintervensi dengan memberi ruang pengecualian bahwa intervensi dapat dilakukan demi perlindungan HAM. Ruang pengecualian ini akan menjadi tonggak hukum baru, di mana instrumen HAM serta AICHR akan terbentuk lebih aktif dan dinamis.

Terdapat tiga alasan dalam penerapan responsibility to protect di ASEAN. Pertama, sebagaimana Pasal 53 ayat (1) Piagam PBB, PBB sejatinya memberikan wewenang terhadap organisasi regional dalam urusan penyelesaian sengketa termasuk dengan melakukan kekerasan. Hal ini mengindikasikan, bahwa penerapan responsibility to protect di ASEAN, tidaklah melanggar hukum. Kedua, ASEAN adalah organisasi regional yang terdiri dari negara-negara yang seluruhnya menjadi anggota PBB. Sedangkan tujuan dibentuknya PBB adalah menjaga perdamaian dunia. Tentu, sebagai negara anggota, ASEAN juga memiliki kewajiban menjaga perdamaian dan keamanan internasional. Ketiga, pemilihan KTT sebagai wadah untuk menerapkan responsibility to protect. Sebagaimana diketahui, KTT adalah perkumpulan seluruh kepala negara ASEAN guna membahas politik ataupun ekonomi. Di sinilah terdapat momentum yang baik guna memaparkan pentingnya penerapan responsibility to protect, meskipun peran politik sangat menentukan dalam merumuskan keputusan.

\section{DAFTAR PUSTAKA}

Charter of the United Nations.

Charter of the Association of South-East Asian Nations (ASEAN).

Christine Susanna Jhin, Menjalin Demokrasi Lokal dengan regional: Membangun Indonesia, Membangun ASEAN, November, 2005.

Departement of Peacekeeping Operations United Nations Secretariat, United Nations Peackeeping Operations: Principles and Guideliness, New York, 2010. 
Direktorat Jenderal Kerja Sama ASEAN Kementerian Luar Negeri RI, Ayo Kita Kenali ASEAN, 2011.

Elfia Farida, Peluang dan Tantangan ASEAN Menuju Komunitas ASEAN 2015, Jurnal MMH, Jilid 41 No. 3 Juli 2012.

Endah Rantau Itasari, Memaksimalkan Peran Treaty of Amity and Cooperation in Southeast Asia 1976 (TAC) dalam Penyelesaian Sengketa di ASEAN, Jurnal Komunikasi Hukum, Volume 1, Nomor 1, Februari 2015, ISSN: 2356-4164.

Eric. A. Heinze, Waging Humanitarian War: The Ethics, Law and Politics of Humanitarian Intervention, United States of America: State University of New York Press, Albany, 2009.

Harjono, Perjanjian Internasional dalam Sistem UUD 1945, jurnal Opinio Juris. Vol. 04, Januari-April 2012.

International Coalition for The Responsibility to protect, 'Sebuah Toolkit tentang Tanggung Jawab Melindungi'.

Ion Panait, From Human Security to Responsibility to protect, Lucian Blaga University, 2014.

Irma D. Rismayati, dalam Jurnal Opini Juris berjudul Manusia Perahu Rohingya: Tantangan Penegakan HAM di ASEAN, Vol 1 Oktober 2009.

John Mark Lyi, Humanitarian Intervention and the AU-ECOWAS Intervention Treaties Under International Law: Towards a Theory of Regional Responsibility to protect, Switzerland: Springer International Publishing AG Switzerland, 2016.

Kholis Roisah, Hukum Perjanjian Internasional: Teori dan Praktek, Malang: Setara Press, 2015.

Ludiro Madu, Pelembagaan Regional Mengenai Hak Asasi Manusia di ASEAN. Jurnal Hubungan Internasional. Vol. 5 Edisi 1/ April 2016.

Mahfud MD, Politik Hukum di Indonesia, Jakarta: Raja Grafindo Persada, 2012.

Merdi Hajiji, Relasi Hukum dan Politik dalam Sistem Hukum Indonesia, Jurnal Rechtsvinding, Volume 2 Nomor 3, Desember 2013.

Rahayu, 'Eksistensi Prinsip Responsibilty to Protect dalam Hukum Internasional', Jurnal MMH, Jilid 41 No. 1 Januari 2012.

Santa Marelda Saragih, Responsibility to protect: Suatu Tanggung Jawab dalam Kedaulatan Negara, Vol 2, Mei-Agustus 2011.

Scott Burchill dan Andew Linklater, Teori-Teori Hubungan Internasional, Bandung: Nusa Media Ujung Bandung, 2009.

Sefriani, Pengakhiran Sepihak Perjanjian Perdagangan Internasional, jurnal Ilmu Hukum, Volume 2 Nomor 1 Tahun 2015.

Stephen P. Marks and Nicolas Cooper, 'The Responsibility to protect; Watershed or Old Wine in a New Bottle', O. P. Jindal Global University, Volume 2, Issue 1, September 2010.

Wahyudi, Djafar dkk, Laporan Penelitian Memperkuat Perlindungan Hak Asasi Manusia di ASEAN, 2014. 
29 | LENTERA HUKUM

William, D. Coplin, Marsedes Marbun, Pengantar Politik Internasional: Suatu Telaah Teoritis. Edisi kedua, Bandung: Sinar Baru, 1992. 
30 | Responsibility to Protect sebagai Bentuk Perlindungan Hak Asasi Manusia di ASEAN

This page is intentionally left blank 